\title{
CONCURRENT VALIDITY OF THE STUDENT TEACHER PROFESSIONAL IDENTITY SCALE
}

\author{
Dr. Predrag Živković, University of Kragujevac, Faculty of pedagogical sciences, \\ Department of humanistic sciences, Jagodina, Serbia
}

E-mail: pedjazvk@gmail.com

\section{A R T I C L E I N F O}

Original Research

Received: December, 05.2017.

Revised: February, 25.2018.

Accepted: March, 05.2018.

doi:10.5937/ijcrsee1801013Z

UDK

371.13

\begin{abstract}
A B S T R A C T
The main purpose of study was to examine concurrent validity of the Student Teachers Professional Identity Scale-STPIS (Fisherman and Abbot, 1998) that was for the first time used in Serbia. Indicators of concurrent validity was established by correlation with student teacher self-reported well-being, self-esteem, burnout stress and resilience. Based on the results we can conclude that the STPIS meets the criterion of concurrent validity. The implications of these results are important for researchers and decisions makers in teacher education
\end{abstract}

\section{Keywords:}

student teacher,

professional identity,

concurrent validity,

correlation.

(C) 2018 IJCRSEE. All rights reserved.

\section{INTRODUCTION}

Teacher educators have been challenged "to recreate the space for construction of an individual, meaningful, resilient professional identity underpinned by strong beliefs and values" (Smethem, 2007:478). Understanding early pre-service teachers' emerging identity may enable teacher educators to prepare pre-service teachers for their teaching career, through facilitating the development of a professional identity as teachers, and eventually the development of effective teachers who thrive in the profession.

The professional identity of future teachers was investigated as a research variable most frequently as a control variable in teacher identity research (Volkmann and Anderson, 1998; Wagnild and Young, 1993; Pillen, 2013; Fisherman and Abbot, 1998; Fisherman and Weiss, 2008; Živković, 2012). Mainly satisfactory and good values of indicators of con-

Corresponding Author

Dr. Predrag Živković, University of Kragujevac, Faculty of pedagogical sciences, Department of humanistic sciences, Jagodina, E-mail: pedjazvk@gmail.com

\section{c) (†) $\ominus$}

This work is licensed under a Creative Commons Attribution - NonCommercial - NoDerivs 4.0. The article is published with Open Access at www.ijcrsee.com current and predictive validity were obtained (Fisherman and Abbot, 1998; Fisherman and Weiss, 2008). Concurrent validity was tested based on the obtained correlation values of score on student teacher professional identity scale and ego-identity, self-regulated learning and meta-cognitive awareness $(\mathrm{p}<0.01)$.

In present study, concurrent validity is understood as a criterion-related validity. This form of validity endeavours to relate the results of one particular instrument to another external criterion. To demonstrate concurrent validity "[...] the data gathered from using one instrument must correlate highly with data gathered from using another instrument" (Cohen, Manion and Morrison, 2007:140). Concurrence can be demonstrated simultaneously with another instrument.

\section{MATERIALS AND METHODS}

The main problem of this research is to examine concurrent validity of the STPIS (Student Teachers Professional Identity Scale) (Fisherman and Abbot, 1998) that was for the first time used in Serbia.

The initial sample of respondents consisted of 158 students from University of Kragujevac, Faculty of Education in Jagodina. The sample comprised of $54.1 \%$ of the $2^{\text {nd }}$ year teacher program students and $45.9 \%$ of those who were the $3^{\text {rd }}$ year and master undergradu- 
ated teacher program group. The study group consisted of 158 participants (131 (83\%) women and $17(17 \%)$ men $(\mathrm{M}=1.83 ; \mathrm{SD}=.375)$, $50(32 \%)$ post-graduated and $108(68 \%)$ under-graduated students ( $\mathrm{M}=1.06 ; \mathrm{SD}=.206)$. Test distribution for academic achievements is normal (Kolmogorov-Smirnov $\mathrm{Z}=1.999$, $\mathrm{p}=0.001, \mathrm{M}=2.46, \mathrm{SD}=.706$ ).

The following instruments were used in the research:

1. Student Teacher Professional Identity Scale (Fisherman and Abbot, 1998)(STPIS).

2. Rosenberg Self-Esteem Scale (RSES) (Rosenberg, 1965; Todorović, 2005).

3. Maslach Teachers Burnout InventoryEducators Survey (MBI-ES)(Maslach et al., 1996).

4. Warwick-Edinburgh Mental Well-being Scale (WEMWBS)(Tennant et al., 2007).

5. Cheung Teacher Professional Identity Scale (Wagnild and Young, 1993).

6. Resilience Scale-RS14 (Wagnild and Young, 1993).

The survey was conducted anonymously and voluntarily in Faculty of Education in Jagodina. The data collection was conducted anonymously to protect confidentiality of the participants. The translation of the RS from English into Serbian was accomplished by a professional translator. The aim of the translation was not to achieve literal or syntactic equivalence, but to maintain the original denotation and connotation of items.

Cronbach's alpha coefficient, the testretest correlation coefficient, and the correlations between the RS and other measures were established by calculating Pearson's correlation coefficients. All statistical analyses used two-tailed tests. For all statistical evaluations, $p$ values less than 0.05 were considered indicative of significant differences.

The statistical analyses were conducted using the Statistical Package for the Social Sciences (SPSS) for Windows, version 17.0. For statistical analysis, p-values lower than .05 were considered statistically significant. The correlations between STPIS and self-reported burnout stress, self-esteem, well-being, resilience and in-service teacher professional identity were calculated using Pearson's correlation analysis.

\section{RESULTS}

The calculated mean score for STPIS was $\mathrm{M}=49.19(\mathrm{SD}=9.47)$. The overall Cron- bach's alpha coefficient of the STPIS was $\alpha=0.935$, indicate good reliability. In the itemstatistics analisys, in Cronbach's Alpha if items deleted section, there were no items that had value above obtained $\alpha=.935$. KMO (.889) and Bartletts test of sphericity $(\mathrm{p}=0.000)$ have satisfactory values. Kolmogorov-Smirnov test of normality $Z=1.264(p=.082)$. The test-retest correlation coefficient of the STPIS was 0.83 , and that of the STPIS- 6 was 0.84 .

Student Teacher Professional Identity Scale (Fisherman and Abbot, 1998)(STPIS). This questionnaire examines students' attitudes towards being a teacher and to how much they identify with teacher's role. The questionnaire examines their confidence about their professional choice, their sense of selfactualization as teachers, and the extent to which they see their profession as a mission and as a challenge. The questionnaire consists of 12 items. The teachers were asked to what extent they agreed with the items on a five-point scale (ranging from 1: complete disagreement, to 5: complete agreement). The total scores ranged from 5 to 60 points. Alpha reliability coefficient in previous study was $\alpha=.93$ (Fisherman \& Abbot, 1998), and in repeted measuring was $\alpha=.84$ (Fisherman and Weiss, 2008).

Rosenberg Self-Esteem Scale (RSES) (Rosenberg, 1965; Todorović, 2005). The RSES assesses the overall sense of being capable, feeling worthwhile, and competence . Internal consistency and factor validity of the Serbian version of the RSES was shown to be high (Todorović, 2005). It consists of 10 items, and the degree of self-esteem for each item is rated on a 7-point Likert scale (range, 10-77). Present study internal reliability by Cronbachs alpha coefficient $\alpha=0.78$.

Maslach Teachers Burnout InventoryEducators Survey (MBI-ES) (Maslach et al., 1996). This scale consists of 22 items. Generally speaking, on our sample of teachers the instrument shows satisfactory metric characteristics (Živković and Grozdanović, 2016). Reliability was determined Crombachs alpha coefficient. The internal reliability of the questionnaire is over 60 (Crombachs alpha coefficient $\alpha=.604$, with standardization value of $\alpha=.633$ ).

Warwick-Edinburgh Mental Well-being Scale (WEMWBS)(Tennant et al., 2007). The WEMWBS comprises 14 positively phrased items which measure positive affect (such as feelings of optimism, cheerfulness, and relaxation), psychological functioning (for example, energy, clear thinking, self-acceptance, 
and competence) and interpersonal relationships. Each item is scored (based on experience over the previous 2 weeks) on a 5-point Likert-style scale from 'none of the time' (1) to 'all of the time' (5). The overall score is the sum of each item score, giving a possible summary score of 14-70; higher scores indicate higher levels of mental well-being (Tennant et al., 2007). Examples of items used in the WEMWBS include: 'I've been dealing with problems well' and 'I've been feeling close to other people'. Calculated Cronbachs Alpha was $\alpha=$.83.

Cheung Teacher Professional Identity Scale (Cheung, 2008). Initial set consisted of 41 items. After determining the psychometric characteristics of the final scale included 18 items (on a 5-point Likert-style scale) that were possessed good psychometric characteristics (Cronbachs Alpha $\alpha=0.83$ ). In our study (Živković, 2013) the reliability calculated for 18 items reached $\alpha=0.87$.

Resilience Scale -RS14 (Wagnild and Young, 1993). A short version of the RS (RS14) was developed (Wagnild, 2009) to provide clinicians and researchers a shorter instrument to reduce participant's burden. The internal consistency of the RS-14 has been reported to be excellent $(\alpha=.93)$ and it correlates strongly $(\mathrm{r}=.97)$ with the original RS (Wagnild, 2009). In a present study, calculated Cronbach's A1pha was $\alpha=.84$.

Indicators of concurrent validity of the STPIS-6 are shown in Table 1. STPIS-6 were negatively correlated with the MBS-ES, and positively correlated with the CTPI, RSES and WEMWBS.

Table 1. Indicators of Concurrent Validity: Correlation Matrix

\begin{tabular}{lcccccc}
\hline & STPIS & RSES & MBS-ES & WEMWBS & CTPI & RS-14 \\
\hline STPIS & 1.000 & \multicolumn{7}{c}{} \\
\hline RSES & $.263^{*}$ & 1.000 & & & & \\
\hline MBS-ES & $.295^{*}$ & .047 & 1.000 & & & \\
\hline WEMWBS & $.278^{*}$ & -.161 & .135 & 1.000 & & \\
\hline CTPI & $.463^{* *}$ & .070 & $.225^{*}$ & .144 & 1.000 & \\
\hline RS-14 & -.005 & .127 & -.185 & -.203 & -.137 & 1.000 \\
\hline \multicolumn{7}{c}{$* *$ Correlation is significant at the 0.01 level } \\
(2-tailed). \\
*Correlation is significant at the 0.05 level \\
(2-tailed).
\end{tabular}

Note: STPIS-Student Teacher Professional Identity Scale; RSES-Rosenberg SelfEsteem Scale; MBS-ES-Maslach Burnout Inventory-Educators Survey; WEMWBSWarwick Edinburgh Mental Well-Being Scale; CTPI-Cheung Teacher Professional Identity Scale; RS-14-Resilience Scale.

\section{DISCUSSIONS}

Theoretical and empirical analyzes in research dealing with the problem of professional identity of teacher students prove or presuppose possible links of identity with wellbeing (Kessels, 2010), self-esteem (Joseph and Heading, 2010), burnout stress (Pillen, 2013) and resilience (Pearce and Morrison, 2011; Papatraianou and Le Cornu, 2014). On our sample of respondents and related instruments that measure the mentioned variables, in order to examine the concurrent validity of the student teacher professional identity scale, values of statistically significant correlations of STPIS with well-being $(\mathrm{r}=.278)$, self-esteem $(\mathrm{r}=.263)$, burnout stress $(\mathrm{r}=.295)$ and inservice teacher professional identity $(\mathrm{r}=.463)$ have been obtained.

The obtained correlation of the resilience and teacher identity is negative and not statistically significant. The obtained negative values of the correlation of resilience and burnout stress (which can be assumed to be significant) indicate the need to examine this relationship in more detail. The obtained high values of the correlation between the in-service teacher professional identity and student teacher professional identity indicate the need to establish and examine latent dimensions in factor and confirmation analysis. All obtained correlation values are expected and are in line with theoretical assumptions, except for the obtained value of the correlation with burnout stress that is supposed to be low and negative (Pillen et al, 2013). Interestingly, a statistically significant correlation of stress with the identity of experienced teachers was obtained $(\mathrm{r}=.225)$.

\section{CONCLUSIONS}

Based on the results we can conclude that the student teacher professional identity scale meets the criterion of concurrent validity. Research on the theme of forming a professional teacher identity is relevant to mentors in the training of future teachers in schools, and their goal is to better understand and conceptualize the support and needs of future teachers.

\section{ACKNOWLEDGEMENTS}

The author gratefully acknowledge the follow Project "Assumptions and Possibilities 
(IJCRSEE) International Journal of Cognitive Research in Science, Engineering and Education Vol. 6, No. 1, 2018.

for Developing Innovative Models of Teaching in the Function of Achieving Transparency of University Education and Raising Competitiveness on the Domestic and Foreign Knowledge Market", a bilateral Project implemented and financed by the Faculty of Pedagogical Sciences of the University of Kragujevac, Jagodina (Republic of Serbia) and the Pedagogical Faculty of the University of Primorska, Kopar (Republic of Slovenia) (2017-2019).

\section{Conflict of interests}

The author declare no conflict of interest.

\section{REFERENCES}

Cheung, H. Y. (2008). Measuring the professional identity of Hong Kong in-service teachers. Journal of In-service Education, 34(3), 375-390. DOI: $10.1080 / 13674580802003060$

Cohen, L., Manion, L., \& Morrison, K. (2013). Research methods in education. Routledge. http://dspace.utamu.ac.ug:8080/xmlui/bitstream/handle/123456789/182/Research-Methods-in-Education-sixth-edition. pdf? sequence $=1 \&$ is Allowed $=\mathrm{y}$

Fisherman, S., \& Abbou, J. A. (1998). Ego identity as a predictor of teaching success. In Paper represented at the Annual Meeting AERA San Diego.

Fisherman, S., \& Weiss, I. (2008). Consolidation of professional identity by using dilemmas among pre-service teachers. Curriculum and Teaching.

Joseph, D., \& Heading, M. (2010). Putting Theory into Practice: Moving from Student Identity to Teacher Identity. Australian Journal of Teacher Education, 35(3). http://dx.doi.org/10.14221/ ajte. $2010 \mathrm{v} 35 \mathrm{n} 3.6$

Kessels, C. (2010). The influence of induction programs on beginning teachers' well-being and professional development (Doctoral dissertation, Leiden University Graduate School of Teaching (ICLON), Leiden University).

Maslach, C., Jackson, S.E, Leiter, M.P. (1996). Maslach Burnout Inventory. (3rd ed.). Paolo Alto, CA: Consulting Psychologists Press. https://www.researchgate.net/profile/Christina Maslach/publication/277816643 The Maslach Burnout Inventory Manual/ links/5574dbd708aeb6d8c01946d7.pdf

Papatraianou, L. H., \& Le Cornu, R. (2014). Problematising the Role of Personal and Professional Relationships in Early Career Teacher Resilience. Australian Journal of Teacher Education, 39(1). http://dx.doi.org/10.14221/ajte.2014v39n1.7

Pearce, J., \& Morrison, C. (2011). Teacher Identity and Early Career Resilience: Exploring the Links. Australian Journal of Teacher Education, 36(1). http://dx.doi.org/10.14221/ajte.2011v36n1.4

Pillen, M., Beijaard, D., \& den Brok, P. (2013). Professional identity tensions of beginning teachers. Teachers and Teaching, 19(6), 660-678. https:// doi.org/10.1080/13540602.2013.827455
Rosenberg, M. (1965). Society and the adolescent selfimage. Princeton, NJ: Princeton University Press. https://books.google.rs/books?hl=sr\&lr= \&id=YR3WCgAAQBAJ\&oi=fnd\&pg=PP1\&d $\mathrm{q}=$ Rosenberg, + M. $+(1965)$

Smethem, L. (2007). Retention and intention in teaching careers: will the new generation stay? Teachers and Teaching: theory and practice, 13(5), 465-480. https://doi. org/10.1080/13540600701561661

Tennant, R., Hiller, L., Fishwick, R., Platt, S., Joseph, S., Weich, S., ... \& Stewart-Brown, S. (2007). The Warwick-Edinburgh mental well-being scale (WEMWBS): development and UK validation. Health and Quality of life Outcomes, 5(1), 63.. https://doi.org/10.1186/1477-7525-5-63

Todorović, J. (2005). Porodični činioci stabilnosti samopoštovanja adolescenata. Zbornik Instituta za pedagoška istraživanja, 37(1), 88-106 [Family Factors of Self-esteem Stability in Adolescence), Journal of the Institute for Educational Research, 37(1), 88-106. https://doi. org/10.2298/ZIPI0501088T

Volkmann, M. J., \& Anderson, M. A. (1998). Creating professional identity: Dilemmas and metaphors of a first-year chemistry teacher. Science Education, 82(3), 293-310. DOI: 10.1002/ (SICI) 1098-237X(199806)82:3<293::AIDSCE1>3.0.CO;2-7

Wagnild, G. (2009). A review of the Resilience Scale. Journal of nursing measurement, 17(2), 105-113. https://doi.org/10.1891/1061-3749.17.2.105

Wagnild, G. M., \& Young, H. M. (1993). Development and psychometric evaluation of the Resilience Scale. Journal of Nursing Measurement, 1(2), 165-178. http://psycnet.apa.org/ record/1996-05738-006

Živković, P. (2012). Profesionalni identitet nastavnika [Teachers professional identity]. Jagodina: Kairos.

Živković, P. (2013). Professional development and teachers professional identity: self-assessment in Republic of Serbia. Journal of Educational and Instructional Studies in the World, 3(1), Article: 18, 150-158. http://www. wjeis.org/FileUpload/ds217232/File/18_ predrag \%C5\%BDivkovi\%C4\%87.pdf

Živković, P., Grozdanović, M. (2016). Factor Analysis of Teacher Burnout Scale. International journal of education, Teacher, 6(2), 6-16. https://www.researchgate.net/profile/Almina Shashko/publication/313388642 New Words In The English Language ${ }^{-}$And $^{-}$ The English Teachers In The Struga Area/ links/ $5898 \mathrm{fa} \overline{49} \mathrm{a} 6 \mathrm{fdcc} 32 \overline{\mathrm{d}} \mathrm{b} \overline{\mathrm{dd}} 0 \mathrm{~d} 4 \overline{9} / \mathrm{New}-\bar{W}$ ordsIn-The-English-Language-And-The-EnglishTeachers-In-The-Struga-Area.pdf\#page $=7$ 